\title{
Scientific and educational cluster as a center of public and private management of construction trades
}

\author{
Rais Safin ${ }^{10000-0003-1864-7876]}$, Ilfak Vildanov ${ }^{1}$, Runar Abitov*1, and Aelina Barieva ${ }^{1}$ \\ ${ }^{1}$ Kazan State University of Architecture and Engineering, 420043 Kazan, Russia
}

\begin{abstract}
The author's definition of applied qualifications is given. It is aimed at the formation of applied qualifications based on resource centers of secondary vocational education institutions that are part of the construction research and education cluster. The principles of organizational and pedagogical conditions of the relations of the resource center with enterprises within the context of public and private administration are identified. The results of the survey among students on the issue of whether they want to learn applied qualifications are given. The organizational and pedagogical conditions of the innovative development of the educational cluster are formulated.
\end{abstract}

Keywords. Scientific and educational cluster, public-private partnership, applied qualifications, resource center, educational and managerial conditions.

\section{Introduction}

The innovative development of the Russian economy is impossible without the presence of highly qualified workers and specialists of different levels of qualification. Due to the elimination of primary vocational training institutions, the issue of training workers remains particularly topical. The solution to this problem was defined in the Decree of the President of the Russian Federation of May 7, 2012 (№ 509). It sets out the short-term task of developing multifunctional application centers based on secondary vocational education institutions. Such centers should be established jointly together with the executive authorities of the constituent entities of the Russian Federation and the all-Russian employers' associations.

The Center for Applied Vocational Qualifications is defined as an organizational structure that provides training to various sectors of the economy, taking into account the needs of the regional (local) labor market through the implementation of vocational training programs (professional modules) [1].

These centers are subdivisions of major regional autonomous software agencies. According to M. Nikitin, training of employees is considered to be of low cost and competitive [2].

In the said centers, employers perform functions of corporate clients, create laboratories, workshops, help improve the quality of vocational training. Methodological recommendations for the formation of multifunctional centers of applied qualifications have been developed by the Ministry of Education and Science of the Russian Federation [3].

*Corresponding author: a_runar@mail.ru 
What does the term «applied qualifications» mean? How are they different from the usual qualifications of the worker? We found the definition of the concept in question in publication of A. Perevertaylo.

Applied Qualifications are those, oriented to the solution of professional tasks within the context of specific labor functions, to the use of existing technologies. Applied qualifications do not imply the creation of new knowledge, and correspond to the 4-6 levels of the National Qualifications Framework [4].

«Applied (professional) qualifications are those that are relevant to professional activities defined by professional standards» [1]. Such a definition is given in the conception of the development of the system of training personnel and the formation of the applied qualifications of the Education Development Institute of the Sverdlovsk Region.

The formation of applied qualifications is the process of training, retraining, and advanced training of workers who are ready to perform a certain type of professional activity, and who have obtained a diploma or a certificate after completion of training.

We understand applied qualifications as additional training or certificates for the performance of a certain type of work obtained in the course of professional education. For example, workers receive additional qualifications in a related area. The students of secondary and tertiary educational institutions receive labor qualification in their branch of activity. What do we have today in the construction industry of Russia?

The Republic of Tatarstan has a regional branch of employers «Union of Construction Workers of the Republic of Tatarstan», which is part of the National Union of Builders. The Union proposed the initiative to create resource centers based on educational institutions, providing vocational training, retraining, advanced training of workers in the sphere of construction based on advanced technologies, and also modern educational and material base has been initiated [5].

At present, there are 79 such resource centers in the Russian Federation. Resource centers should be licensed for the right to conduct educational activities; educational facilities, appropriate teaching staff; a developed material and technical base; and partnerships with construction organizations and construction self-regulated organizations in a given specific region.

The main objectives of the resource center are:

- Meeting the needs of construction companies for highly skilled workers capable of rapid adaptation in the workplace;

- Improvement of public-private partnership arrangements for the training of skilled workers; development of partnership between the economy and education institutions;

- Improvement of the educational and material basis for the training of skilled workers;

- Implementation of regional training programs for workers [5].

The resource center is based on the following principles:

- The principle of social partnership, involving the implementation of forms of cooperation between the state, non-profit and commercial sectors of the economy;

- The principle of network organization of a regional (interregional) system of continuing professional education;

- The principle of continuity of education, which provides a learning transition from one educational program to another based on the interaction of educational institutions in the industry, the continuity of programs of different levels and orientation;

- The principle of continuity in the content and organization of the learning process;

- The principle of collective access to the resources of the center, which ensures the interaction of the resources available to unidimensional vocational training institutions;

- Self-development principle, which provides for the establishment of a mechanism for the activities of the center based on order under the conditions of co-creation and co-financing [6]. 
Resource centers that use innovative educational programs in accordance with the world standards and with documented applications from the building companies of self-regulating organizations are given the status of basic ones.

There are 17 such centers in Russia. The largest number of centers is located in Moscow (7) and the Northwest Federal District (5). In the Volga Federal District, the basic resource centers were created based on the Perevozsk secondary vocational college (Nizhny Novgorod Region). There is no such center in Tatarstan yet [5].

The only resource center was established in Tatarstan based on Kazan Construction College. There are plans to train workers in the following trades: concrete worker, mason, plasterer, tiler, carpenter. Other construction trades are not prepared in the Republic.

In addition, the creation of resource centers based on secondary vocational institutions requires:

- Implementation of the set of measures to strengthen the innovative educational environment in the basic vocational education institution;

- Creation of special structures, providing organizational, educational, and methodological support for innovative approaches in training, the constant interaction of the basic vocational education institution with key employers;

- Introduction of a significant number of specific educational programs of innovationtype into the educational process, relevant to the priority directions of the sectoral economy;

- Ensuring high quality training, vocational training, and advanced training of students;

- Development of professional competences among graduates that determine their competitiveness in the labor market, ensuring their career and personal growth [7-10].

The purpose of the study is to design goals, principles of organizational and pedagogical conditions of interaction of the resource center with enterprises within the context of statepublic administration, a model of training of qualified teachers for the system of secondary vocational education. The aim of the study is the process of training of teachers and formation of psychological and educational qualifications in the conditions of the scientific and educational cluster. The subject of this study lies in the model for the training of future teachers for the secondary vocational education system in scientific and educational cluster.

\section{Materials and methods}

The methodological basis of the study is comprised of the principles of social partnership of educational systems and enterprises or, in other words, the clients of the scientific and educational cluster. The research process has applied a set of theoretical and empirical methods. Theoretical methods included: study, analysis and synthesis of Russian pedagogical design of conditions of interaction of resource center with enterprises, pedagogical designing. Empirical methods: surveillance, interviews, questionnaires.

The pedagogical design is considered to be a special activity aimed at the creation of innovative management of the pedagogical educational process in the scientific and educational cluster. At the same time, it acts as a scientific and practical method of learning and transforming of reality, as a form of innovation, and as a management procedure. The pedagogical design was carried out in three stages:

- Designing of the organizational and educational conditions of the relationship of the resource centre with the enterprises of the industry;

- Designing of the process of providing a system of secondary vocational education with qualified teachers with integrated psychological, pedagogical and applied construction qualifications in the scientific and educational cluster;

- Development of a model for teacher training for secondary vocational training organizations.

The experimental work was conducted at KSUAE. The process was monitored by means of interviews with learners. 145 students were interviewed. 
From the above, it is the leading idea of building a new model of public and social management of the resource center, providing for the transfer of part of managerial authority and responsibility for their implementation to social partners. At the same time, the organizational and pedagogical conditions of the relationship between the resource center with enterprises - social partners $[11,12]$.

The first condition: the relationship between a resource center with enterprises - social partners should be based on a system approach.

The system of resource center relationships with social partners in public administration should be seen as an independent pedagogical system with its interrelated structural components: purpose, content, methods, activities of subjects of the educational process, and production $[12,13]$.

The structural components are integrative in nature: an integral goal to bring accordance to the achievement of the various objectives in the training of personnel; the integral content of the relationships to contribute to the formation of applied (professional) qualifications and competencies of workers and specialists in the construction field, etc.

The second condition: the resource center with enterprises must have a competent approach.

These relationships are also integrative in nature and are based on the integration of an activity-oriented and personalized approach aimed at developing professional skills and competencies and developing specific professional and personal qualities of workers and professionals who determine their willingness to engage in creative work.

The third condition: the relationship of resource center with social partners relationship system must be open in nature.

Openness implies the interaction of the resource center with enterprises based on legal acts. In implementing the resource center relationship system with the enterprise, the resource center becomes part of the innovative system of the enterprise, and part of knowledge management, supporting the production and transfer of knowledge and technologies in the field of modern knowledge-intensive production, motivation of innovative behavior of the public-private partnership of resource center and enterprise.

It should be noted that public administration not only provides additional means to the resource center but also becomes a guarantee of its high flexibility and adequacy to the requirements of the regional economy. The educational system of the resource center for the employer is opened in the form of the enterprise, which is effectively involved in the development and implementation of state educational policy, formation of lists of training of workers and specialists, in the implementation of state educational standards of vocational education, formation of a significant part of the content of educational programs, participation in the procedures of quality control of vocational training.

Openness changes the role of the state in the public-private partnership system - there is a shift from the state mono-management of the resource center to public administration by ensuring the smooth and efficient interaction of the resource center entities and enterprises. At the same time, the functions of the state as regulator of interaction between the participants in the system of public-private partnership are considerably strengthened.

Meanwhile, there are regulatory mechanisms for the dialogue between the resource center and the users of human resources, including a critical indicator of success and efficiency of customer satisfaction, which leads to an increase in the investment attractiveness of the resource center through the transparency and openness of public and private partnership for all stakeholders and structures, to the orientation of educational results to the demands of employers; to increase the level of quality assurance of the formation of applied qualifications, corresponding to the quality of the formation of applied qualifications to the employers' requirements as customers and consumers; to lower the costs of vocational training in general concerning guaranteed and agreed extrabudgetary funding. 
The fourth condition: the resource center's relationship system with enterprises should ensure the innovative nature of vocational training in public administration.

Vocational training is now being transformed into a cluster policy aimed primarily at innovative enterprises, high technology, knowledge-intensive sectors.

Taking into account the desire of enterprises to increase production capacity and increase the economic efficiency of production, to improve the quality of products and accompanying services, to increase the production and to supply of products, to expand and strengthen cooperation with partners and consumers, it is logical to assume that they need highly qualified workers and specialists, actively leading technical re-equipment of enterprises and introduction of new technologies. In this regard, one of the directions in the design of the resource center's relationship with enterprises is to ensure the innovative nature of professional training of workers and specialists. The innovative nature of training takes place through the integration of a number of educational programs with real production, including through the provision of educational services to enterprises.

Fifth Condition: The design target for state-public management of the resource center should be defined.

Design and target provision of a public management system of the resource center includes the design of professionally important personal qualities of a worker or a specialist and a variety of his activities; a professional standard; curriculum structure; structure of the learning process with a clear reflection in the combination of theoretical and practical training of trainers; agreements of the resource center with enterprises on the main areas and forms of mutually beneficial cooperation; guidance and recommendations for the assistance of the students; and multi-party training educators, as well as the resource center development programs.

Sixth condition: mechanisms must be developed to harmonize educational and professional standards in accordance with the requirements of the new generation of state educational standards and requirements of the modern construction complex.

Professional standards will allow for the establishment and maintenance of uniform quality requirements, the identification of new labor trends, and the development of job descriptions for staff. They form the basis for the certification of employees according to uniform criteria. The requirements for the performance of workers in the labor market make it possible to define the objectives, structure, content of educational standards of vocational training and modular educational programs based on competence.

Designing a relationship system that is adapted to the modern requirements of enterprises for the educational and training opportunities of the resource center also calls for the development of mechanisms for the harmonization of educational and professional standards. At the same time, in the framework of public-private partnership, the professional standard should not only be agreed with the new generation of state educational standards, but also meet modern innovative requirements of specific enterprises. One way to develop mechanisms for the harmonization of educational and professional standards is the use of the integrative module and competence approach in the management of the quality of the training of workers and specialists, and the development of professional standards and their constituent application and functional competencies on this basis.

A professional standard is for a resource center based on applied qualifications, the basis for subsequent development of curricula and programs, and an assessment of the level of proficiency in the relevant professional standard.

The module allows the development of mechanisms for harmonization of educational and professional standards in accordance with the requirements of the new generation of state educational standards and requirements of the modern construction complex, brings together the system of vocational training and the sphere of economy, labor market [14]. Unity is achieved by transforming the requirements of the labor market, requirements of the construction industry to the qualification and competence of the employee in the quality 
requirements of the final result of the training process, namely, to the quality of the employee's applied (professional) qualifications $[15,16]$.

Gareyev's work [5] contains a forecast of training needs in the construction industry for 2014-2016. The demand for workers reaches 5669 people, and specialists with higher education -5317 . The author notes that educational facilities, production training, craftsmen, and curricula [17] have been lost in educational institutions in the region.

This condition with the centers of applied qualifications requires the adoption of urgent measures to develop the applied qualifications of workers and specialists in the construction industry of the Republic of Tatarstan.

In addition, the reorganization of existing secondary vocational educational institutions has resulted in the deterioration of the educational and material bases of the latter. It is known that technical schools did not train workers and did not have well-equipped training workshops. Many schools have handed over their training buildings to the municipal authorities and the workshops have been liquidated.

It is also known that, due to the modernization of the vocational education system, the elimination of the level of primary vocational education, and the transfer of secondary vocational education to regional management, there is an outflux of experienced teachers and masters of production education from educational institutions. This is facilitated by low wages and difficulties in the scientific and methodical work with the introduction of new federal State educational standards. Therefore, providing a system of secondary vocational education with qualified teachers is one of the topical issues of vocational education.

In our opinion, this problem can be solved in the framework of creating research and education cluster based on KSUAE. At present, the cluster includes «Kazan Construction College», «Bugulma Construction and Technical College», «Naberezhnyye Chelny Economy and Construction College».

In the near future, it is planned to include the Kazan College of Public Utilities and Construction and the Nizhnekamsk Industrial College. Then the applied qualifications of workers and technicians will be formed in colleges, and engineering staff (academic and applied bachelors and masters) are being trained in the construction university. Undergraduates will be able to get work applications in colleges. In addition, students of the University and Colleges will be able to study the modern technologies of KNAUF in the training and consulting center. KSUAE also has «Vocational Training» master's and doctoral courses. The process of formation of multi-level vocational education in the industrial cluster is oriented towards the design of new content of study, change of educational and methodological support, and transformation of the organizational structure of educational institutions of the system.

All this is possible if there are highly qualified, professionally trained teachers at all levels of education who are able and willing to carry out serious scientific and methodological research, to determine the required production competence, to develop monitoring and evaluation materials to monitor the effectiveness of the training process. However, this aspect of the problem is not widely discussed in the scientific literature.

\section{Results and discussion}

At present, KSUAE has a bachelor's degree program «Vocational Training (Industry)». KSUAE also has a department and faculty to train students within the framework of this program. The department is conducting scientific research within the context of the federal targeted program «Scientific and scientific-pedagogical personnel of innovative Russia» aimed at the training of scientific and pedagogical personnel, at the influx of young people into the sphere of science and education. The teachers of the department carry out research in the framework of the comprehensive program «Development of vocational education: scientific foundations and innovations for 2011-2015, supervised by the Ministry of Science 
and Education» According to the results of the grant, one $\mathrm{PhD}$ and one Dr. Hab theses were defended. The Department has held 7 international scientific and practical conferences with the publication of collections of materials. The department conducts courses for doctoral study in education and pedagogical sciences. All this allows to develop the educational environment and ensures a high level of training of graduates aimed at educational institutions of secondary vocational education, training centers of applied qualifications of the Republic of Tatarstan [18-26].

The scheme of training of future teachers for the level of secondary vocational education and the training centers of vocational education in the scientific and educational cluster of the KSUAE is shown in Fig 1.

At the same time, as mentioned earlier, the scientific and educational cluster may also act as a center for the formation of applied qualifications of workers and specialists.

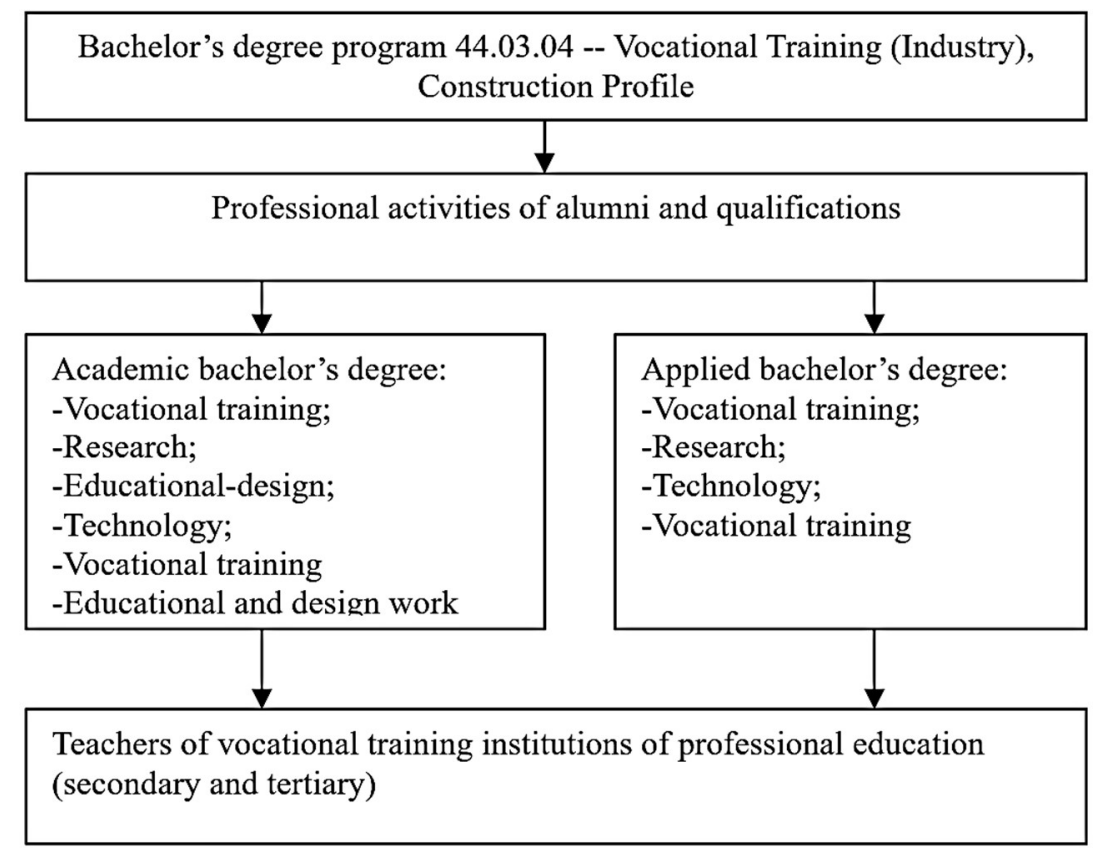

Fig. 1. Scheme of training of future teachers at the level of secondary vocational education, vocational training centers in the scientific and educational cluster of KSUAE.

The benefits of developing applied skills and certification of new technologies and materials in the scientific and educational cluster are as follows:

- An innovative growth environment is being created to motivate and focus students on professional growth; [27]

- Creation of favorable conditions for the career development of workers and specialists as they pass the appropriate level of professional education;

- The continuous growth of the levels of vocational education by training in master's degree, post-graduate studies, joint seminars, competitions, conferences, and exhibitions is ensured.

As a disadvantage in the application development process in the cluster, there are currently no training workshops at the university to provide training for workers. It can be overcome by a network organization of the learning process within a cluster in the secondary vocational institutions that are part of the cluster.

Of course, it was interesting to know the views of the students themselves, whether they wanted to be trained in the learning process. A total of 145 students were interviewed, 
studying Industrial and Civil Engineering. These students are studying in the laboratory of modern technologies created by KNAUF. After passing the exams, they receive a certificate to work with the materials, using their technology. The survey showed the following.

$92 \%$ of the respondents confirmed the need and relevance of the development of applied skills. $75 \%$ of students plan to work in the construction industry in the future. As the most important components for the development of applied qualifications, students identified:

- The existence of a modern educational base $-86 \%$;

- The opportunity to learn using modern construction technologies, equipment, and materials in practical exercises $-75 \%$;

- The qualification of teachers is $88 \%$ of the students interviewed.

$91 \%$ of respondents are satisfied with the level of formation of applied qualifications for work with technologies and materials.

Thus, the survey showed the relevance of the formation of applied qualifications in the process of their professional training at the university.

\section{Conclusion}

In conclusion, it should be noted that the development of applied qualifications is possible if:

1) The principles of innovative development of the education cluster in the systemic integration of science, education and production are defined.

2) Organizational-pedagogical conditions for innovative development of educational cluster are implemented:

2.1 Integrated scientific and methodological, training, information and technical support for training of workers and formation of applied skills.

2.2 Network organization of the educational cluster on the principles of social partnership through targeted and organized involvement of educational, informational, methodological, innovative, human resources, consulting and other resources of business and production [27].

2.3 Forms of organization of production practices that ensure the effectiveness of formation of professional skills, application of knowledge in real activity, practical development of modern equipment and technologies.

2.4 Training of faculty for the implementation of modular training and applied training programs.

2.5 The integration of students' academic and research activities throughout the application of the Bachelor's degree program.

\section{References}

1. G. Development and D. of the S. region, I. of Education, (2014).

2. N.M.V., Accredit. Educ. 6, 36 (2012).

3. Methodological Recommendations for the Formation of Multifunctional Centers of Applied Qualifications. Moscow, (2013).

4. Perevertailo A., (2014).

5. K.S.V., Second. Vocat. Educ. 2, 7 (2014).

6. L. Yarullina, D. Shigapova, L. Abdrahmanova, T. Suchkova, A. Barieva, E. Nikonova, IOP Conf. Ser. Mater. Sci. Eng., (2020).

7. R.K. Gilmeeva, P.V. Solovyova, E.I. Nikonova, L.G. Pak, T.I. Shulga, V.N. Perekrestov, A.L. Makarov, Eurasian J. Anal. Chem. 12, 1059 (2017).

8. R.K. Gilmeeva, V.A. Ignatova, V.V. Nevolina, M.Y. Fadeyeva, V.V. Kurushin, N.V. Kosolapova, V.A. Mishchenko, Eurasian J. Anal. Chem. 12, 1117 (2017). 
9. T. Spirchagova, A. Nasyrova, D. Vakhitova, L. Sadrieva, T. Brodskaya, Int. J. Instr. 10, 79 (2017).

10. B.I.R., State and Public Administration of an Educational Institution of Secondary Vocational Education, (2011).

11. M.A. Kashina, S.G., Chudnovskiy, A.D., Aleksandrova, N.S., Shamov, I.V., Borovaya, Math. Educ. 11 (3), 447 (2016).

12. Z.F. Yusupova, M.M. Shakurova, N.Y. Saygushev, O.A. Vedeneeva, S.G. Kashina, Int. Rev. Manag. Mark. 6, 403 (2016).

13. P.V. Stankevich, S.V. Abramova, E.N. Boyarov, Man India 97, 117 (2017).

14. I.V. Terentyeva, O. Kirillova, T. Kirillova, N. Pugacheva, A. Lunev, I. Chemerilova, A. Luchinina, Int. J. Educ. Manag. 32, 1041 (2018).

15. Y.L. Kamasheva, V.V. Zemskov, S.G. Kashina, B.V. Shagiev, V.V. Baranov, E.I. Tikhomirova, Man India 97, 67 (2017).

16. G.I.F., KSUAE, Kazan, 342-347 (2013).

17. R.S. Safin, E.A. Korchagin, T.V. Suchkova, I.E. Vildanov, R.N. Abitov, Espacios 39, (2018).

18. R.R. Khairutdinov, R.S. Safin, E.A. Korchagin, F.G. Mukhametzyanova, A.V. Fakhrutdinova, S.R. Nikishina, Int. J. Instr. 12, 357 (2019).

19. R.S. Safin, E.A. Korchagin, Rev. Eur. Stud. 7, 168 (2015).

20. E.A. Korchagin, R.S. Safin, Vyss. Obraz. v Ross. 28, 67 (2019).

21. L.G. Akhmetov, O.V. Kirillova, T.V. Kirillova, A.V. Varlamov, S.G. Kashina, R.S. Safin, E.V. Leonova, I.A. Sharonov, Int. Rev. Manag. Mark. 6, 34 (2016).

22. R.S. Safin, E.A. Korchagin, V.A. Elizarova, I.E. Vildanov, R.N. Abitov, N.A. Kora, V.M. Nigmetzyanova, Asian Soc. Sci. 11, 269 (2015).

23. R.S. Safin, A.R. Shaidullina, R.A. Alikhanova, I.V. Muskhanova, T.V. Yusupkhadzhieva, L.A. Dzhamalkhanova, F.V. Mezhidova, V.M. Nigmetzyanova, L.G. Akhmetov, Int. Rev. Manag. Mark. 6, 51 (2016).

24. R.S. Safin, E.A. Korchagin, Middle East J. Sci. Res. 16, 1094 (2013).

25. A.N. Lunev, R.S. Safin, E.A. Korchagin, D.K. Sharafutdinov, T.V. Suchkova, L.V. Kurzaeva, S.R. Nikishina, N.A. Kuznetsova, Int. Rev. Manag. Mark. 6, 166 (2016).

26. O.V. Kirillova, T.V. Kirillova, L.A. Abramova, I.V. Gavrilova, M.I. Vaibert, Eur. J. Contemp. Educ. 6, 280 (2017).

27. I.A. Korshunov, G.A. Chakhoyan, A.M. Tyunin, E.R. Lyakhovetskaya, Obraz. i Nauk. 23, 73 (2021). 